\title{
URIC ACID CLEARANCE IN NORMAL PREGNANCY AND PRE-ECLAMPSIA ${ }^{1}$
}

\author{
By N. K. SCHAFFER, L. V. DILL, ANd J. F. CADDEN \\ (From the Department of Obstetrics and Gynecology, Cornell University Medical College, and \\ the New York Hospital, New York City)
}

(Received for publication September 14, 1942)

A rise in blood uric acid without nitrogen retention is the most consistent blood chemical finding in pre-eclampsia and eclampsia $(1,2)$. It is not known whether this hyperuricemia is of renal or metabolic origin. A disturbance of uric acid metabolism in the liver has been suggested (1). The idea that it may result from an elevated blood lactic acid has been shown to be untenable (3). Its possible relation to the hypertension in the disease has been mentioned, since a similar hyperuricemia has been reported in essential hypertension (4) and has been obtained experimentally (5) with the kidney pressor substance, renin.

Previous evidence has not indicated that a reduced uric acid excretion is of particular importance as a cause of the hyperuricemia. Cadden and Stander (1) found that the uric acid excreted daily in eclampsia was not essentially different from the normal. Nayar (6) reported a 13 per cent reduction in the uric acid clearance in eclampsia, but this was associated with a 61 per cent rise in the blood uric acid. However, recent reports ( 7 to 9 ) are in agreement that the glomerular filtration is reduced in these pregnancy toxemias. For this reason, we have investigated the uric acid clearance in normal pregnancy and in pre-eclampsia to determine its role in the hyperuricemia of the disease.

\section{METHODS}

Ten patients with the clinical diagnosis of pre-eclampsia, and 12 who were clinically normal, were the subjects of this study. Three other patients with unclassified pregnancy toxemia were also studied. Uric acid clearances were done on all patients in the last trimester, as close to term as possible. In 4 pre-eclamptic, 3 unclassified, and 4 normal patients, the clearance was repeated at about 8 days postpartum. Most of the patients had renal function studied by simultaneous inulin, diodrast, and urea clearances, which were reported elsewhere (9).

${ }^{1}$ Supported by a grant from the John and Mary $R$. Markle Foundation.
All patients were well hydrated in order to obtain a good urine flow.2 They were given a liter of water to drink at bedtime the night before the clearance was to be determined, and $200 \mathrm{cc}$. at 5:00, 5:30, and 6:00 a.m. At $6: 20$ a.m., a constant intravenous infusion of the inulin and diodrast solution was started and continued to the end of the test. At 7:00 a.m., the first clearance was begun after emptying the bladder by injecting 50 to $100 \mathrm{cc}$. of air, 3 times. The starting time was taken after the last air injection. Usually, 3 urine collections of 15 to 30 minutes duration were made. When the urine flow was below $2 \mathrm{cc}$. per minute, the urine was collected for periods up to 60 minutes. The bladder was emptied with air at the end of each urine collection. A blood sample was taken midway in both the first and third urine collections.

All clearances were calculated using the maximum clearance formula with plasma values (except urea where whole blood values were used) and were corrected to a body surface area of $1.73 \mathrm{sq}$. M. The reported clearances were generally averages from 2 or 3 clearance periods taken on one day. In the case of uric acid, no clearance was averaged when the urine flow was below $1 \mathrm{cc}$. per minute, the augmentation limit assumed for uric acid by Brøchner-Mortensen (10). With inulin, no clearance was averaged below a urine flow of about $1.1 \mathrm{cc}$. per minute. ${ }^{3}$ No urea clearance was averaged below a urine flow of $2 \mathrm{cc}$. per minute.

Plasma tungstic acid filtrates were prepared by adding $4.5 \mathrm{cc}$. of water to $1 \mathrm{cc}$. of plasma, followed by $0.5 \mathrm{cc}$. of 10 per cent sodium tungstate, and slowly adding $4 \mathrm{cc}$. of N/12 sulfuric acid. Uric acid was determined on this filtrate by the method of Folin $(12,13)$. Urine uric acid ${ }^{4}$ was determined by the direct method of Folin (13).

2 An 8 per cent mannitol infusion is recommended (8) as a diuretic for toxemia patients that give low urine flows. This was not used in the present study.

8 In the present series of normal pregnant patients, this urine flow was about the limit below which the inulin clearance occasionally fell. Since Chasis (11) found no decrease in the inulin clearance at a urine flow as low as 0.6 cc. per minute in man, the present decreases were due to collection errors that occur especially in late pregnancy $(8,9)$.

1 One of us (N. K. S.) will show elsewhere that practically all the uric acid in human urine, as determined by the direct Folin method, is true uric acid, as determined by the uricase method (14). The same has previously (2) been shown to be true for the blood uric acid in preeclampsia and eclampsia. 
TABLE I

Uric acid clearance in normal pregnancy

\begin{tabular}{|c|c|c|c|c|c|c|c|c|c|c|c|c|c|}
\hline \multirow{2}{*}{ Case } & \multirow{2}{*}{ Age } & \multirow{2}{*}{$\begin{array}{c}\text { Surface } \\
\text { area }\end{array}$} & \multirow{2}{*}{$\begin{array}{l}\text { Gra- } \\
\text { vida }\end{array}$} & \multirow{2}{*}{$\begin{array}{c}\text { Week of } \\
\text { preg- } \\
\text { nancy }\end{array}$} & \multirow{2}{*}{$\begin{array}{c}\text { Blood } \\
\text { pressure }\end{array}$} & \multirow{2}{*}{$\begin{array}{l}\text { Protein- } \\
\text { urea }\end{array}$} & \multirow{2}{*}{ Edema } & \multirow{2}{*}{$\begin{array}{c}\text { Plasma } \\
\text { uric acid }\end{array}$} & \multirow{2}{*}{$\underset{\text { urea-N }}{\text { Blood }}$} & \multirow{2}{*}{$\begin{array}{l}\text { Average } \\
\text { urine flow }\end{array}$} & \multicolumn{2}{|c|}{ Plasma clearances } & \multirow{2}{*}{$\begin{array}{c}\text { Urea } \\
\text { clearance }\end{array}$} \\
\hline & & & & & & & & & & & $\begin{array}{l}\text { Uric } \\
\text { acid }\end{array}$ & Inulin & \\
\hline & years & sq. $M$. & & & $m m . H_{g}$ & & & $\begin{array}{c}\text { mem. } \\
\text { per cent }\end{array}$ & per cent & $\begin{array}{l}\text { cc. per } \\
\text { minute }\end{array}$ & $\begin{array}{l}\text { cc. per } \\
\text { minute }\end{array}$ & $\begin{array}{l}\text { cc. per } \\
\text { minute }\end{array}$ & $\begin{array}{l}\text { cc. per } \\
\text { minute }\end{array}$ \\
\hline
\end{tabular}

ANTEPARTUM

\begin{tabular}{|c|c|c|c|c|c|c|c|c|c|c|c|c|c|}
\hline $\begin{array}{r}1 A \\
2 A \\
3 A \\
4 A \\
5 A \\
6 A \\
7 A \\
8 A \\
9 A \\
10 A \\
11 A \\
12 A \\
\text { Mean }\end{array}$ & $\begin{array}{l}34 \\
30 \\
37 \\
32 \\
35 \\
31 \\
34 \\
40 \\
24 \\
25 \\
38 \\
32\end{array}$ & $\begin{array}{l}1.63 \\
1.68 \\
1.70 \\
1.63 \\
1.65 \\
1.87 \\
1.66 \\
1.52 \\
1.52 \\
1.60 \\
1.40 \\
1.60\end{array}$ & $\begin{array}{l}6 \\
2 \\
2 \\
1 \\
4 \\
3 \\
1 \\
4 \\
4 \\
2 \\
2 \\
5 \\
3\end{array}$ & $\begin{array}{l}40 \\
38 \\
36 \\
39 \\
40 \\
40 \\
32 \\
40 \\
36 \\
32 \\
40 \\
40\end{array}$ & $\begin{array}{l}115 / 78 \\
106 / 70 \\
110 / 72 \\
120 / 80 \\
118 / 68 \\
128 / 100 \\
120 / 70 \\
128 / 80 \\
105 / 50 \\
120 / 70 \\
120 / 70 \\
120 / 75\end{array}$ & $\begin{array}{l}0 \\
0 \\
0 \\
0 \\
0 \\
0 \\
0 \\
0 \\
0 \\
0 \\
0 \\
0\end{array}$ & $\begin{array}{l}0 \\
0 \\
0 \\
0 \\
+ \\
0 \\
0 \\
0 \\
0 \\
0 \\
0 \\
0\end{array}$ & $\begin{array}{l}4.40 \\
4.43 \\
3.82 \\
3.93 \\
3.51 \\
4.62 \\
2.89 \\
3.91 \\
3.84 \\
2.67 \\
4.68 \\
3.23 \\
3.83\end{array}$ & $\begin{array}{r} \\
7.4 \\
6.0 \\
7.5 \\
7.5 \\
6.1 \\
9.9 \\
10.0 \\
8.0 \\
7.8\end{array}$ & $\begin{array}{l}0.94 \\
2.82 \\
2.36 \\
2.47 \\
4.32 \\
7.16 \\
2.12 \\
1.34 \\
1.44 \\
4.94 \\
4.44 \\
4.44 \\
3.23\end{array}$ & $\begin{array}{l}28.3 \\
23.1 \\
19.8 \\
33.2 \\
29.8 \\
21.3 \\
43.8 \\
38.3 \\
35.2 \\
43.3 \\
30.2 \\
36.7 \\
31.9\end{array}$ & $\begin{array}{r} \\
121 \\
120 \\
150 \\
131 \\
115 \\
67 \\
144 \\
117\end{array}$ & $\begin{array}{c}126 \\
97.3 \\
95.5 \\
78.2 \\
125 \\
62.1 \\
88.0 \\
91.3\end{array}$ \\
\hline
\end{tabular}

POSTPARTUM

\begin{tabular}{r|r|r|l|l|l|l|l|l|l|l|l|l|r}
\hline 5A & 35 & 1.51 & 4 & $7 \dagger$ & $130 / 80$ & 0 & 0 & 3.98 & 12.3 & 5.22 & 34.8 & 171 & 83.4 \\
$6 \mathrm{~A}$ & 31 & 1.77 & 3 & 8 & $110 / 70$ & 0 & 0 & 4.26 & 11.9 & 5.49 & 23.4 & 108 & 71.7 \\
$9 \mathrm{~A}$ & 24 & 1.46 & 2 & 9 & $120 / 70$ & 0 & 0 & 4.08 & 11.8 & 6.49 & 32.3 & 158 & 119 \\
$13 \mathrm{~A}$ & 21 & 1.51 & 1 & 9 & $120 / 70$ & 0 & 0 & 4.41 & 13.0 & 1.96 & 26.7 & 115 & 86.5 \\
Mean & & & & & & & & 4.18 & 12.3 & 4.79 & 29.3 & 138 & 90.1 \\
\hline
\end{tabular}

* Average urine flow only for uric acid clearance.

When the urine contained an appreciable amount of protein, the analysis was made after deproteinization with acetic acid and heat, or on a tungstic acid filtrate prepared by adding $3.5 \mathrm{cc}$. of water to $2 \mathrm{cc}$. of urine, followed by $0.5 \mathrm{cc}$. of 10 per cent sodium tungstate, and slowly adding $4 \mathrm{cc}$. of $\mathrm{N} / 12$ sulfuric acid.

Plasma and urine inulin were determined by the method of Alving, Rubin, and Miller (15). Urea was determined on whole blood filtrate by the manometric hypobromite method of Van Slyke and Kugel (16). Urine urea plus ammonia was similarly determined (17) without removing protein.

\section{RESULTS}

A summary of the clinical data and of the uric acid, inulin, and urea clearances is given in Table I for the normal patients and in Table II for the pre-eclamptic and unclassified groups. It is seen that the antepartum plasma uric acid was elevated in most of the pre-eclamptic cases and that the mean (5.29 mgm. per cent) was 38 per cent higher than the mean for the normal group (3.83 $\mathrm{mgm}$. per cent). The uric acid clearance showed a decrease in the pre-eclamptic group commensurate with the increase of blood uric acid. The antepartum normal clearance averaged 31.9 cc. per minute as compared with 21.9 cc. per minute for the pre-eclamptic group, a decrease of 31 per cent. Despite considerable variation of the values in both groups, both the decrease of the clearance and the elevation of blood uric acid in the preeclamptic group were statistically significant (Table III). Thus, the "significance of the difference of the means" was 2.5 for the uric acid clearance and 3.8 for the blood uric acid. The distribution of the uric acid clearance values is shown in graph form in Figure 1. It is apparent that the pre-eclamptic clearances are generally lower than the normal clearances at all urine flows.

Since pre-eclamptic patients usually begin to recover after delivery and show a gradual return of the blood uric acid to normal, the effects of the disease may also be shown by comparing their antepartum and postpartum values. In 4 preeclamptic patients, the average blood uric acid at about 10 days postpartum was $4.54 \mathrm{mgm}$. per cent 
TABLE II

Uric acid clearance in pre-eclampsia and unclassified pregnancy toxemia

\begin{tabular}{|c|c|c|c|c|c|c|c|c|c|c|c|c|c|c|}
\hline \multirow{2}{*}{ Case } & \multirow{2}{*}{$\begin{array}{l}\text { Mild or } \\
\text { severe }\end{array}$} & \multirow{2}{*}{ Age } & \multirow{2}{*}{$\begin{array}{l}\text { Sur- } \\
\text { face } \\
\text { area }\end{array}$} & \multirow{2}{*}{$\begin{array}{l}\text { Gra- } \\
\text { vida }\end{array}$} & \multirow{2}{*}{$\begin{array}{c}\text { Week of } \\
\text { preg- } \\
\text { nancy }\end{array}$} & \multirow{2}{*}{$\begin{array}{c}\text { Blood } \\
\text { pressure }\end{array}$} & \multirow{2}{*}{$\begin{array}{l}\text { Protein- } \\
\text { urea }\end{array}$} & \multirow{2}{*}{ Edema } & \multirow{2}{*}{$\begin{array}{c}\text { Plasma } \\
\text { uric } \\
\text { acid }\end{array}$} & \multirow{2}{*}{$\begin{array}{c}\text { Blood } \\
\text { urea- } \\
\mathbf{N}\end{array}$} & \multirow{2}{*}{$\begin{array}{c}\text { Average } \\
\text { urine } \\
\text { flow* }\end{array}$} & \multicolumn{2}{|c|}{ Plasma clearances } & \multirow{2}{*}{$\begin{array}{c}\text { Urea } \\
\text { clearance }\end{array}$} \\
\hline & & & & & & & & & & & & $\begin{array}{l}\text { Uric } \\
\text { acid }\end{array}$ & Inullin & \\
\hline & & years & sq. $M$. & & & mm. $\boldsymbol{H}_{\boldsymbol{l}}$ & & & per cent & per cent & $\begin{array}{l}\text { cc. per } \\
\text { minute }\end{array}$ & $\begin{array}{l}\text { cc. per } \\
\text { minute }\end{array}$ & $\begin{array}{l}\text { cc. per } \\
\text { minute }\end{array}$ & $\begin{array}{l}\text { cc. per } \\
\text { minute }\end{array}$ \\
\hline
\end{tabular}

ANTEPARTUX PRE-ECLAMPSIA

\begin{tabular}{|c|c|c|c|c|c|c|c|c|c|c|c|c|c|c|}
\hline $\begin{array}{c}\text { 1B } \\
2 \mathrm{~B} \\
3 \mathrm{~B} \\
4 \mathrm{~B} \\
5 \mathrm{~B} \\
6 \mathrm{~B} \\
7 \mathrm{~B} \\
8 \mathrm{~B} \\
9 \mathrm{~B} \\
10 \mathrm{~B} \\
\text { Mean } \\
\text { Percen }\end{array}$ & $\begin{array}{l}\mathbf{M} \\
\mathbf{M} \\
\mathbf{M} \\
\mathbf{S} \\
\mathbf{S} \\
\mathbf{S} \\
\mathbf{S} \\
\mathbf{S} \\
\mathbf{S} \\
\mathbf{S}\end{array}$ & $\begin{array}{l}25 \\
32 \\
35 \\
20 \\
23 \\
34 \\
27 \\
22 \\
31 \\
22\end{array}$ & $\begin{array}{l}1.69 \\
1.86 \\
1.99 \\
1.53 \\
1.69 \\
1.66 \\
1.68 \\
1.73 \\
1.64 \\
1.73\end{array}$ & $\begin{array}{l}4 \\
1 \\
8 \\
1 \\
3 \\
1 \\
1 \\
1 \\
2 \\
1\end{array}$ & $\begin{array}{l}26 \\
40 \\
40 \\
38 \\
28 \\
37 \\
39 \\
38 \\
40 \\
36\end{array}$ & $\begin{array}{l}150 / 94 \\
150 / 100 \\
135 / 90 \\
150 / 112 \\
152 / 102 \\
160 / 100 \\
142 / 94 \\
140 / 90 \\
140 / 90 \\
150 / 100\end{array}$ & $\begin{array}{l}c e \\
+ \\
+\end{array}$ & $\begin{array}{c}+\underset{T r}{+} \\
\text { Tr. } \\
++ \\
+++ \\
0 \\
0 \\
\text { Tr. } \\
\text { Tr. } \\
++\end{array}$ & $\begin{array}{r}\mathbf{3 . 9 2} \\
\mathbf{5 . 5 4} \\
\mathbf{6 . 9 2} \\
4.23 \\
4.63 \\
\mathbf{3 . 9 5} \\
\mathbf{5 . 3 9} \\
\mathbf{5 . 9 3} \\
\mathbf{7 . 1 2} \\
\mathbf{5 . 2 7} \\
\mathbf{5 . 2 9} \\
+\mathbf{3 8 . 1}\end{array}$ & $\begin{array}{r}11.9 \\
8.6 \\
8.7 \\
7.3 \\
12.0 \\
\\
9.7 \\
+24.4\end{array}$ & $\begin{array}{r}2.80 \\
3.98 \\
1.47 \\
3.26 \\
3.34 \\
2.98 \\
1.31 \\
2.25 \\
1.01 \\
1.10 \\
2.35 \\
-27.2\end{array}$ & $\begin{array}{r}14.8 \\
23.3 \\
12.8 \\
18.8 \\
35.2 \\
36.7 \\
34.7 \\
22.1 \\
12.9 \\
7.8 \\
21.9 \\
-31.3\end{array}$ & $\begin{array}{c}96 \\
84 \\
\\
150 \\
141 \\
107 \\
43 \\
38 \\
94 \\
-19.7\end{array}$ & $\begin{array}{c}56.1 \\
38.7 \\
74.0 \\
108 \\
74.2\end{array}$ \\
\hline
\end{tabular}

POSTPARTUM PRE-ECLAMPSIA

\begin{tabular}{r|l|l|l|l|l|l|l|l|l|l|r|r|r|r|r}
\hline 2B & $\mathrm{M}$ & 32 & 1.75 & 1 & $8 \dagger$ & $140 / 90$ & Trace & 0 & 3.81 & 9.6 & 4.47 & 22.2 & 122 & 67.5 \\
6B & $\mathrm{S}$ & 34 & 1.59 & 1 & 11 & $123 / 75$ & 0 & 0 & 4.43 & 8.1 & 4.92 & 33.3 & 37 & 60.4 \\
7B & $\mathrm{S}$ & 27 & 1.59 & 1 & 10 & $130 / 95$ & Trace & 0 & 4.45 & 12.5 & 5.46 & 31.7 & 95 & 66.9 \\
9B & $\mathrm{S}$ & 31 & 1.53 & 2 & 10 & $110 / 90$ & Trace & 0 & $\mathbf{5 . 4 8}$ & $\mathbf{1 2 . 3}$ & $\mathbf{6 . 2 7}$ & 36.2 & 146 & 113 \\
Mean & & & & & & & & & & 4.54 & 10.6 & 5.28 & 30.9 & 100 & 77.0 \\
\hline
\end{tabular}

ANTEPARTUM UNCLASSIFIED TOXEMTA

\begin{tabular}{|c|c|c|c|c|c|c|c|c|c|c|c|c|c|}
\hline $\begin{array}{r}1 C \\
2 C \\
3 C \\
\text { Mean }\end{array}$ & $\begin{array}{l}22 \\
25 \\
24\end{array}$ & $\begin{array}{l}1.52 \\
1.91 \\
1.83\end{array}$ & $\begin{array}{l}2 \\
2 \\
2\end{array}$ & $\begin{array}{l}38 \\
34 \\
39\end{array}$ & $\begin{array}{l}135 / 90 \\
160 / 105 \\
160 / 105\end{array}$ & $\begin{array}{c}+t+ \\
\text { Trace } \\
++++\end{array}$ & $\begin{array}{c}0 \\
0 \\
\text { Tr. }\end{array}$ & $\begin{array}{l}7.13 \\
3.84 \\
5.24 \\
5.40\end{array}$ & $\begin{array}{l}8.6 \\
8.6\end{array}$ & $\begin{array}{l}1.38 \\
1.46 \\
4.41 \\
2.42\end{array}$ & $\begin{array}{l}14.3 \\
23.6 \\
15.0 \\
17.6\end{array}$ & $\begin{array}{r}113 \\
97 \\
58 \\
89\end{array}$ & $\begin{array}{l}73.4 \\
73.4\end{array}$ \\
\hline
\end{tabular}

POSTPARTUM UNCLASSIFIED TOXEMIA

\begin{tabular}{r|l|l|l|l|l|l|l|l|l|l|l|l|l|l|l|l|}
\hline $1 \mathrm{C}$ & 22 & 1.43 & & 2 & $6 \dagger$ & $140 / 90$ & + & 0 & 3.27 & 9.6 & 2.99 & 37.4 & 129 & 91.6 \\
$2 \mathrm{C}$ & 20 & 1.85 & & 2 & 9 & $130 / 90$ & ++ & 0 & 3.98 & 10.4 & 6.33 & 27.0 & 142 & 94.9 \\
$3 \mathrm{C}$ & 24 & 1.78 & & 2 & 6 & $140 / 90$ & Trace & 0 & 4.64 & 10.4 & 9.22 & 20.4 & 160 & 51.0 \\
Mean & & & & & & & & & &
\end{tabular}

* Average urine flow only for uric acid clearance.

† Days postpartum

TABLE III

Statistical summary of antepartum uric acid clearance and blood uric acid data

\begin{tabular}{|c|c|c|c|c|c|c|c|}
\hline & & $\begin{array}{l}\text { Number } \\
\text { of cases }\end{array}$ & Range & Mean & - & $\sigma_{m}$ & $\begin{array}{l}\text { Significance of } \\
\text { difference of means }\end{array}$ \\
\hline $\begin{array}{l}\text { Plasma uric acid } \\
\text { clearance }\end{array}$ & $\begin{array}{c}\text { Normal pregnancy } \\
\text { Pre-eclampsia }\end{array}$ & $\begin{array}{l}12 \\
10\end{array}$ & $\begin{array}{r}19.8 \text { to } 43.8 \\
7.8 \text { to } 36.7\end{array}$ & $\begin{array}{l}31.9 \\
21.9\end{array}$ & $\begin{array}{r}7.67 \\
10.51\end{array}$ & $\begin{array}{l}2.22 \\
3.33\end{array}$ & 2.5 \\
\hline Plasma uric acid & $\begin{array}{c}\text { Normal pregnancy } \\
\text { Pre-eclampsia }\end{array}$ & $\begin{array}{l}12 \\
10\end{array}$ & $\begin{array}{l}2.67 \text { to } 4.68 \\
3.92 \text { to } 7.12\end{array}$ & $\begin{array}{l}3.83 \\
5.29\end{array}$ & $\begin{array}{l}0.628 \\
1.08\end{array}$ & $\begin{array}{l}0.182 \\
0.343\end{array}$ & 3.8 \\
\hline
\end{tabular}




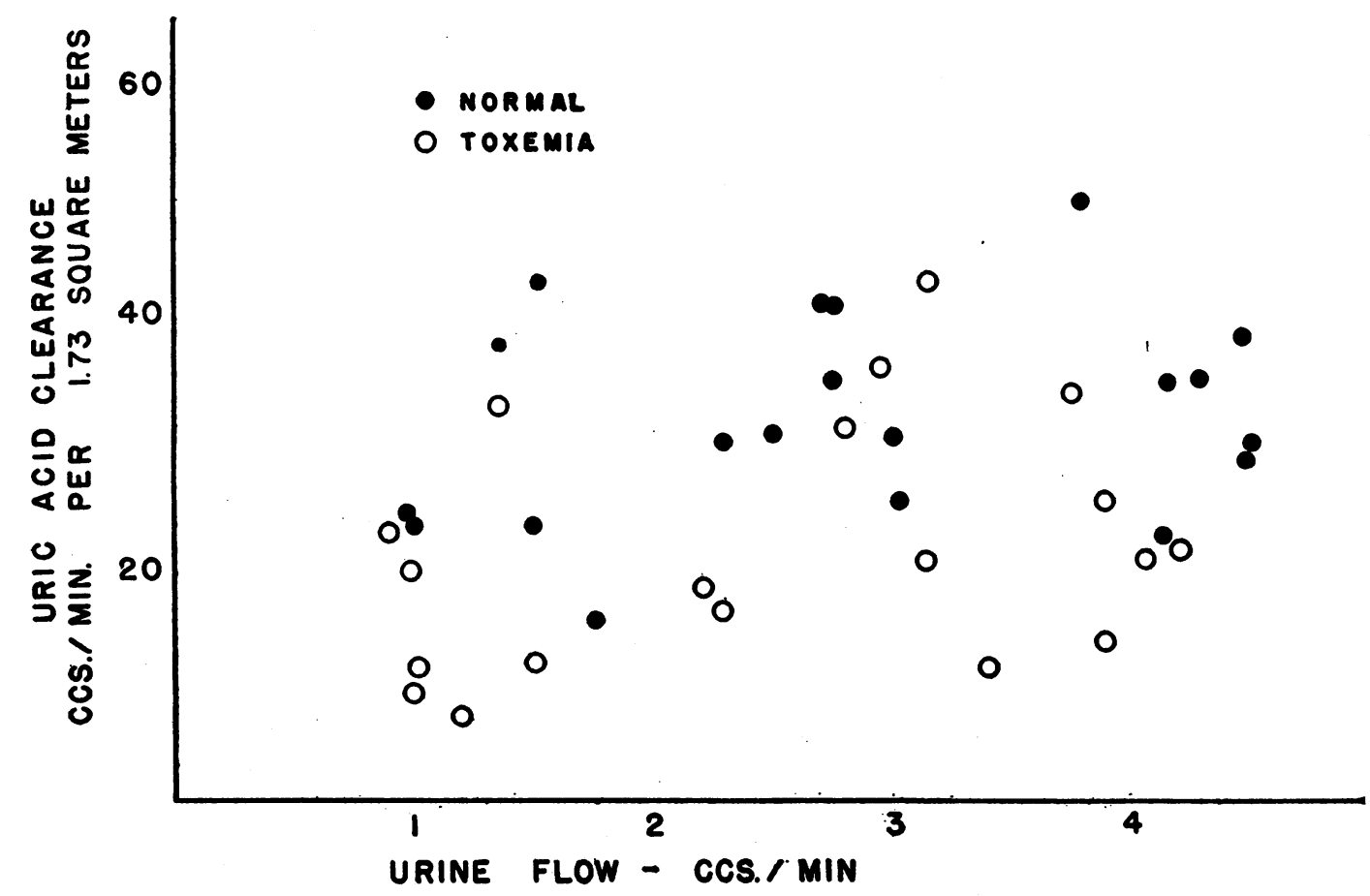

Fig. 1. Distribution of Uric Acid Clearances in Antepartum Normal Pregnancy and in Toxemic Pregnancy

as compared with their antepartum value of $\mathbf{5 . 5 0}$ mgm. per cent, or a rise of 21 per cent antepartum. The uric acid clearance postpartum was $30.9 \mathrm{cc}$. per minute and antepartum, 26.9 cc. per minute, or a decrease of 13 per cent antepartum. In 3 normal patients, the postpartum values differed by only a small percentage from their antepartum values.

One normal patient (case 7A) was of particular interest in that she subsequently developed severe pre-eclampsia (case 6B). The normal uric acid clearances determined in both the 31st and $33 \mathrm{rd}$ weeks of pregnancy were the same, 43.8 cc. per minute. The toxemic clearance in the 37 th week of pregnancy was 36.7 cc. per minute, a decrease of 16 per cent. The blood uric acid rose 37 per cent. The postpartum changes showed a further decrease in the clearance with a rise in the blood uric acid.

The 3 unclassified toxemia patients also showed an antepartum hyperuricemia ( +41 per cent) and decreased uric acid clearance ( -45 per cent) relative to the normal group, and with corresponding changes of +36 and -38 per cent when compared with their postpartum values.
The inulin clearance, studied in 8 normal and 7 pre-eclamptic patients, was rendered 20 per cent in the toxemic group antepartum and rose postpartum. The urea clearance was reduced 23 per cent and the blood urea was increased 22 per cent in 6 cases of antepartum pre-eclampsia as compared with 7 normal cases.

\section{DISCUSSION}

It would appear from the finding of a decrease of about one-third in the uric acid clearance associated with a similar increase in the blood uric acid in pre-eclampsia, that a reduced clearance of this substance primarily accounts for the hyperuricemia. Additional evidence is given by the postpartum fall in blood uric acid and rise in the clearance in the toxemic group and by the changes found in one patient before and after becoming pre-eclamptic. Also consistent with this is that the 3 toxemic patients (cases $3 \mathrm{~B}, 9 \mathrm{~B}, 1 \mathrm{C}$ ) with the highest blood uric acid values had a greater decrease in the uric acid clearance antepartum and the greatest rise postpartum (cases $8 \mathrm{~B}, 1 \mathrm{C}$ ). Their average blood uric acid was $7.06 \mathrm{mgm}$. per cent, or 84 per cent higher than normal, and their 
average clearance was 13.3 cc. per minute, or 58 per cent lower than normal.

The data on the inulin clearance in pre-eclampsia agree with previous reports (7 to 9) of a diminished glomerular filtration in the disease and indicate the probable origin of the decreased uric acid and urea clearances. The reduction in the urea clearance is also in agreement with previous reports (18 to 20). The absence of an elevated blood urea (relative to the nonpregnant normal value) when the blood uric acid is raised in pre-eclampsia is apparently due to the fact that pregnancy normally lowers blood urea but not blood uric acid (21).

While Nayar (6) found a decreased uric acid clearance ( -13 per cent) in eclampsia, consistent with the present work, his failure to obtain a commensurate rise in blood uric acid (he found +61 per cent) was probably due to several causes. Above all, the urine flows in his series (average in normal pregnancy $=0.56 \mathrm{cc}$. per minute, average in eclampsia $=0.74 \mathrm{cc}$. per minute) were at a level where collection errors are likely to occur (see footnote 3). Also he assumed that the augmentation limit for uric acid was the same as that for urea, 2 cc. per minute, whereas Br $\phi$ chner-Mortensen (10) has shown that it generally lies between $0.5 \mathrm{cc}$. and $1 \mathrm{cc}$. per minute and has taken it to be $1 \mathrm{cc}$. per minute. Some difference in the blood uric acid between his and our series might be expected from the fact that his patients had eclampsia and ours had pre-eclampsia. For example, an elevated blood lactic acid from the eclamptic convulsions might temporarily raise the blood uric acid (3). However, the hyperuricemia of both pre-eclampsia and eclampsia is believed to be due fundamentally to the same cause.

\section{SUMMARY}

The average plasma uric acid clearance in 12 cases of antepartum normal pregnancy was 31.9 cc. per minute, and in 10 cases of antepartum preeclampsia, it was $21.9 \mathrm{cc}$. per minute, or a reduction of 31 per cent in pre-eclampsia. The average plasma uric acid in the corresponding groups was 3.83 and $5.29 \mathrm{mgm}$. per cent, or an increase of 38 per cent in pre-eclampsia. These changes, which are statistically significant, indicate that the hyperuricemia of pre-eclampsia (and eclampsia) may be due to a decrease in the uric acid clearance.
The inulin and urea clearances were reduced simultaneously with the uric acid clearance in pre-eclampsia, and indicate that the decreased uric acid and urea clearances were due to a reduction in glomerular filtration.

The absence of an elevated blood urea when the blood uric acid is raised in pre-eclampsia is apparently due to the fact that pregnancy normally lowers blood urea but not blood uric acid.

\section{BIBLIOGRAPHY}

1. Cadden, J. F., and Stander, H. J., Uric acid metabolism in eclampsia. Am. J. Obst. and Gynec., 1939, $37,37$.

2. Schaffer, N. K., and Stander, H. J., True uric acid in hyperuricemia of pre-eclampsia and eclampsia. Proc. Soc. Exper. Biol. and Med., 1940, 45, 180.

3. Schaffer, N. K., Barker, S. B., Summerson, W. H., and Stander, H. J., Relation of blood lactic acid and acetone bodies to uric acid in pre-eclampsia and eclampsia. Proc. Soc. Exper. Biol. and Med., 1941, 48, 237.

4. Brøchner-Mortensen, $K$., The uric acid content in blood and urine in health and disease. Medicine, 1940, 19, 161.

5. Schaffer, N. K., Dill, L. V., and Stander, H. J., The effect of renin on the uric acid metabolism of the pregnant and non-pregnant Dalmatian dog. Endocrinology, 1941, 29, 243.

6. Nayar, A. S. M., Biochemical investigation of eclampsia. J. Obst. and Gynaec. Brit. Emp., 1940, 47, 404.

7. Corcoran, A. C., and Page, I. H., Renal function in late toxemia of pregnancy. Am. J. M. Sc., 1941, 201, 385.

8. Wellen, I., Welsh, C. A., Taylor, H. C., Jr., and Rosenthal, A., The filtration rate, effective renal blood flow, tubular excretory mass and phenol red clearance in specific toxemia of pregnancy. $J$. Clin. Invest., 1942, $21,63$.

9. Dill, L. V., Isenhour, C. E., Cadden, J. F., and Schaffer, N. K., Glomerular filtration and renal blood flow in the toxemias of pregnancy. Am. J. Obst. and Gynec., 1942, 43, 32.

10. Brøchner-Mortensen, $K$., Uric acid in blood and urine. Acta med. Scandinav., 1937, suppl. 84, 3.

11. Chasis, H., cited in Smith, H. W., The Physiology of the Kidney. Oxford University Press, New York, 1937.

12. Folin, O., Standardized methods for the determination of uric acid in unlaked blood and in urine. J. Biol. Chem., 1933, 101, 111.

13. Folin, O., The preparation of sodium tungstate free from molybdate, together with a simplified process for the preparation of a correct uric acid reagent (and some comments). J. Biol. Chem., 1934, 106, 311. 
14. Blauch, M. B., and Koch, F. C., A new method for the determination of uric acid in blood with uricase. J. Biol. Chem., 1939, 130, 443.

15. Alving, A. S., Rubin, J., and Miller, B. F., A direct colorimetric method for the determination of inulin in blood and urine. J. Biol. Chem., 1939, 127, 609.

16. Van Slyke, D. D., and Kugel, V. H., Improvements in manometric micro-kjeldahl and blood urea methods. J. Biol. Chem., 1933, $102,489$.

17. Van Slyke, D. D., Page, I. H., Hiller, A., and Kirk, E., Studies of urea excretion. IX. Comparison of urea clearances calculated from the excretion of urea, of urea plus ammonia, and of nitrogen de- terminable by hypobromite. J. Clin. Invest., 1935, $14,901$.

18. Stander, H. J., Duncan, E. E., and Sisson, W. E., Chemical studies on the toxemias of pregnancy. Bull. Johns Hopkins Hosp., 1925, 36, 411.

19. Cadden, J. F., and McLane, C. M., Study of various kidney function tests in relation to toxemias of pregnancy. Surg., Gynec. and Obst., 1934, 59, 177.

20. Dieckmann, W. J., Renal function in toxemias of pregnancy. Am. J. Obst. and Gynec., 1935, 29, 472.

21. Peters, J. P., and Van Slyke, D. D., Quantitative Clinical Chemistry. Interpretations. Williams and Wilkins, Baltimore, 1932. Pp. 338, 435. 